\title{
GAMBARAN BAKTERI DAN SENSITIVITAS ANTIBIOTIK PADA PASIEN STROKE DENGAN SEPSIS DI RUANG NEUROLOGI RSUP HAJI ADAM MALIK MEDAN
}

\author{
BACTERIAL PATTERN AND ANTIBIOTICS SENSITIVITY OF SEPSIS \\ STROKE PATIENTS IN NEUROLOGY INPATIENT ROOMS OF HAJI ADAM MALIK \\ GENERAL HOSPITAL MEDAN
}

Etiya Ekayana, * Aida Fithrie, * Irina Kemala Nasution*

\section{ABSTRACT}

Introduction: Stroke patients are at high risk of sepsis because of the immune-suppressive effect of cerebral damage and the immobilization due to neurological deficit. The choice of empiric antibiotics for sepsis depends on epidemiology data of the bacterial pattern and antibiotics sensitivity.

Aims: To know the incidence rate, bacterial pattern and antibiotics sensitivity of sepsis stroke patients in Haji Adam Malik General Hospital.

Methods: A descriptive study of sepsis stroke patients in intensive stroke corner care and neurology ward of Adam Malik General Hospital, Medan, during February 2018-June 2018. The diagnosis of sepsis was based on the Criteria of American College of Chest Physicians (ACCP) and Society of Critical Care Medicine (SCCM).

Results: From total of 153 stroke patients admitted between February and June 2018, 28.2\% stroke patients were identified with sepsis; 20 patients in stroke corner and 23 patients in neurology ward. The average of time to develop sepsis was $4.74 \pm 1.9$ days based on the increasing of procalcitonin level in blood. Aerobic and gram negative organisms were dominating the microbiologic spectrum $(97.7 \%$ and $86 \%$, respectively). The most common etiology of sepsis in were Klebsiella pneumonia and Acinetobacter baumanii. The most sensitive antibiotics were amikacin and meropenem.

Discussion: There were $28.3 \%$ subjects diagnosed with sepsis due to Klebsiella pneumonia (40\%) and Acinetobacter baumanii (39.1\%) infection which are aerobic gram negative bacteria. Amikacin and meropenem were the most sensitive antibiotics against the bacteria which cause the sepsis.

Keywords: Antibiotic sensitivity, bacterial pattern, sepsis, stroke

\section{ABSTRAK}

Pendahuluan: Adanya kerusakan serebral (cerebral injury) berefek penekanan terhadap sistem imun serta imobilisasi akibat defisit neurologis menyebabkan pasien stroke berisiko tinggi untuk mengalami sepsis. Pemilihan antibiotik empiris pada sepsis tergantung pada data epidemiologi dari pola bakteri dan sensitivitas antibiotik.

Tujuan: Untuk mengetahui persentase kejadian sepsis dan gambaran bakteri dan sensitivitas antibiotik pada pasien stroke dengan sepsis di ruang rawat inap Neurologi RSUP Haji Adam Malik.

Metode: Studi deskriptif pada pasien stroke dengan sepsis di ruang intensif stroke corner dan ruang rawat inap terpadu (Rindu) RSUP Haji Adam Malik, Medan selama Februari-Juni 2018. Diagnosis sepsis didasarkan pada Kriteria American College of Chest Physicians (ACCP) dan Society of Critical Care Medicine (SCCM).

Hasil: Dari total 152 pasien stroke yang dirawat pada bulan Februari hingga Juni 2018 dijumpai sebanyak 28,2\% yang mengalami sepsis; yang terdiri dari 20 orang di stroke corner dan 23 orang di bangsal neurologi. Rerata waktu terjadinya sepsis adalah $4,74 \pm 1,9$ hari dengan peningkatan rerata kadar prokalsitonin. Bakteri yang paling banyak dijumpai adalah tipe aerob (97,7\%) dan gram negatif (86\%). Jenis bakteri penyebab sepsis tersering adalah Klebsiella pneumonia, Acinetobacter baumanii. Antibiotik yang paling sensitif adalah amikasin dan meropenem.

Diskusi: Didapatkan $28,2 \%$ subjek yang mengalami sepsis dengan bakteri penyebab terbanyak adalah Klebsiella pneumonia (40,0\%) dan Acinetobacter baumanii (39,1\%) yang merupakan bakteri aerob gram negatif. Amikasin dan meropenem merupakan antibiotik yang memiliki sensitivitas yang tinggi terhadap bakteri penyebab sepsis tersebut.

Kata Kunci: Gambaran bakteri, sensitivitas antibiotik, sepsis, stroke

*Departemen Neurologi FK Universitas Sumatera Utara/RSUP Haji Adam Malik, Medan. Korespondensi: etiya_ekayana@yahoo.co.id.

\section{PENDAHULUAN}

Aktivasi sistem kekebalan tubuh bawaan dan adaptif berperan penting pada stroke, yaitu monosit sebagai sel utama pada sistem imun bawaan yang memengaruhi sistem imun didapat. Monosit dapat mencapai sistem saraf pusat pada 4 jam pertama dari onset akibat kerusakan sawar darah otak pasca-injury serebral karena stroke, meskipun infiltrasi maksimal terjadi setelah 7 hari. $^{1}$ 
Dalam uji eksperimental pada stroke iskemik, monosit dapat mencetuskan terjadinya inflamasi. Pada pasien dengan stroke akut, ada peningkatan yang signifikan dalam jumlah monosit yang beredar, dan kenaikan ini sangat mencolok pada pasien yang mengalami stroke terkait infeksi. Oleh karena itu, pasien stroke mudah terjadi infeksi akibat imunodepresi. ${ }^{1}$

Pada pasien stroke iskemik akut, terjadi peningkatan jumlah sel monosit di darah, dan menggambarkan perubahan fenotipe yang berkurang pada saat ekspresi dari molekul antigen dan rendahnya produksi dari TNF proinflamasi, juga produksi dari anti-inflamasi IL-10 yang berubah. Perubahan ini penting dan berhubungan dengan risiko infeksi pascastroke. ${ }^{1}$

Selain itu, kurangnya imobilisasi pada pasien stroke juga merupakan faktor risiko terjadinya infeksi. Hubungan antara imobilisasi dan infeksi bersifat dua arah, infeksi sering menyebabkan pasien beristirahat dan imobilisasi. Dalam sebuah penelitian pasien dirawat di RS dengan penyakit medis selama dua bulan, didapatkan bahwa imobilisasi merupakan penyebab paling umum terjadinya infeksi. ${ }^{2}$

Salah satu infeksi serius pascastroke adalah sepsis. ${ }^{3}$ Sepsis merupakan disregulasi respons tubuh secara sistemik terhadap infeksi yang dapat menyebabkan disfungsi organ berupa sepsis berat dan syok sepsis. Syok sepsis adalah sepsis berat disertai hipotensi yang tidak teratasi dengan resusitasi cairan. ${ }^{4-6}$ Penelitian Berger dkk terhadap 238 pasien stroke iskemik dan hemoragik mendapatkan kejadian sepsis sebanyak $12,6 \%$ dengan sumber infeksi utama dari paru-paru $(93,3 \%)$ akibat organisme gram positif. $^{3}$

Risiko infeksi kemungkinan sebesar 33\% pada iskemik serebral dan $58 \%$ pada pendarahan intraserebral. Sumber infeksi yang paling sering adalah saluran pernapasan dan saluran kemih. Selain menyebabkan perawatan di RS yang lebih lama, infeksi merupakan faktor risiko yang dapat menyebabkan luaran buruk pada pasien stroke. ${ }^{3}$

Pemberian antibiotik definitif pada pasien sepsis didasarkan pada temuan kultur bakteri dengan uji sensitifitas dan resistensinya yang membutuhkan waktu cukup lama. Padahal pemberian antibiotik harus diberikan secepat mungkin setelah diagnosis sepsis, sehingga dibutuhkan penggunaan terapi antibiotik empiris. Pemilihan terapi antibiotik empiris membutuhkan data pola kuman dan sensitivitas antibiotik sebagai data klinis untuk menentukan terapi antibiotik yang tepat pada pasien stroke dengan sepsis. ${ }^{7}$

\section{TUJUAN}

Untuk mengetahui persentase kejadian sepsis dan gambaran bakteri dan sensitivitas antibiotik pada pasien stroke dengan sepsis yang dirawat di RSUP Haji Adam Malik, Medan.

\section{METODE}

Penelitian ini bersifat deskriptif dengan metode potong lintang terhadap penderita stroke dengan sepsis yang dirawat di RSUP Haji Adam Malik, Medan, pada bulan Februari hingga Juni 2018. Adapun kriteria inklusi adalah pasien stroke yang ditegakkan berdasarkan anamnesis, pemeriksaan fisik, dan CT scan kepala yang memenuhi kriteria sepsis, menjalani perawatan selama minimal 48 jam, serta setuju untuk ikut dalam penelitian. Adapun kriteria eksklusi adalah subjek dengan riwayat pemakaian antibiotik sebelum perawatan.

Kriteria sepsis adalah ditemukannya minimal 2 dari kriteria Systemic Inflammatory Respons Syndrome (SIRS), yaitu: demam $\left(\geq 38^{\circ} \mathrm{C}\right)$ atau hipotermia $\left(\leq 36^{\circ} \mathrm{C}\right)$, denyut nadi $\geq 90 \mathrm{kali} /$ menit, frekuensi napas $\geq 20 \mathrm{kali} /$ menit atau $\mathrm{PaCO} 2$ $<32 \mathrm{mmHg}$, dan kadar leukosit $>12.000 / \mathrm{mm}^{3}$ atau $<4.000 / \mathrm{mm}^{3}$ atau $>10 \%$ immature band. ${ }^{4-5}$ Perawatan dilakukan di ruang intensif stroke corner dan ruang rawat inap terpadu (Rindu) RSUP Haji Adam Malik, Medan. Subjek dilakukan pemeriksaan kadar prokalsitonin sebagai penanda sepsis (kadar nomal $<0,5 \mathrm{ng} / \mathrm{mL}$ ), kultur darah, sputum, dan urin, serta uji sensitivitas antibiotik. Diagnosis klinis infeksi dinyatakan berdasarkan sumber temuan pada kultur bakteri, yaitu pneumonia berdasarkan kultur dari sputum, infeksi saluran kemih berdasarkan kultur dari urin, dan infeksi aliran darah jika ditemukan kuman dari kultur darah. ${ }^{4,7}$

Semua pasien yang secara klinis diduga sepsis dirawat bersama dokter spesialis penyakit dalam 
untuk sekaligus menegakkan diagnosis sepsis. Waktu terjadinya sepsis ditetapkan pada saat hari pengambilan kultur yang dinyatakan positif dijumpai bakteri dan secara klinis memenuhi kriteria sepsis. Pengambilan kultur dilakukan minimal hari ke-2 perawatan untuk menyingkirkan infeksi dari luar RS. Pasien juga telah diberikan fisioterapi pasif dan mobilisasi pasif untuk pencegahan infeksi.

Data hasil penelitian dianalisis secara statistik menggunakan program SPSS. Untuk melihat gambaran pola kuman bakteri dan sensitivitas antibiotik pada pasien stroke dengan sepsis digunakan analisis deskriptif.

\section{HASIL}

Dari total 152 pasien stroke yang dirawat pada bulan Februari hingga Juni 2018 dijumpai sebanyak

Tabel 1. Karakteristik Demografi dan Klinis Subjek $(n=43)$

\begin{tabular}{|c|c|}
\hline Karakteristik & n (\%) \\
\hline Jenis Kelamin & $22(51,2)$ \\
\hline - Perempuan & $21(48,8)$ \\
\hline \multicolumn{2}{|l|}{ - Laki-laki } \\
\hline \multicolumn{2}{|l|}{ Jenis Stroke } \\
\hline - Stroke iskemik & $35(81,4)$ \\
\hline - Stroke hemoragik & $8(18,6)$ \\
\hline \multicolumn{2}{|l|}{ - Tingkat Kesadaran } \\
\hline - Sadar penuh & $6(14)$ \\
\hline - Penurunan kesadaran & $37(86)$ \\
\hline $\begin{array}{l}\text { Waktu Terjadinya Sepsis, } \\
(\text { Rerata } \pm \text { SD) Hari }\end{array}$ & $4,74 \pm 1,9$ \\
\hline \multicolumn{2}{|l|}{ Jenis Kultur } \\
\hline - Sputum & $29(67,4)$ \\
\hline - Darah & $8(18,6)$ \\
\hline - Urin & $6(14,0)$ \\
\hline \multicolumn{2}{|l|}{ Jenis Bakteri } \\
\hline - Aerob & $42(97,7)$ \\
\hline - Anaerob & $1(2,3)$ \\
\hline \multicolumn{2}{|l|}{ Pewarnaan Gram } \\
\hline - Gram positif & $6(14,0)$ \\
\hline - Gram negatif & $37(86,0)$ \\
\hline \multicolumn{2}{|l|}{ Sumber Infeksi } \\
\hline - Pneumonia & $29(67,4)$ \\
\hline - Infeksi aliran darah & $8(18,6)$ \\
\hline - Infeksi saluran kemih & $6(14,0)$ \\
\hline $\begin{array}{l}\text { Kadar Prokalsitonin (Rerata } \pm \text { SD) } \\
\text { ng/mL }\end{array}$ & $6,93 \pm 14,36$ \\
\hline
\end{tabular}

43 orang $(28,2 \%)$ pasien stroke yang mengalami sepsis yang terdiri dari 20 subjek di ruang stroke corner dan 23 subjek di ruang rawat inap terpadu Neurologi (Tabel 1). Sebanyak 37 subjek (86\%) mengalami penurunan kesadaran. Rerata usia subjek adalah $59,41 \pm 12,28$ tahun dengan proporsi laki-laki hampir sama dengan perempuan, yaitu 21 orang $(48,8 \%)$ dan 22 orang $(51,2 \%)$. Mayoritas subjek menderita stroke iskemik $(81,4 \%)$ dan pneumonia $(67,4 \%)$, dengan rerata durasi terjadinya sepsis sekitar 4,74 $\pm 1,9$ hari dan kadar prokalsitonin yang meningkat $(6,93 \pm 14,36 \mathrm{ng} / \mathrm{mL})$.

Bakteri yang paling banyak dijumpai (Tabel 1) adalah tipe aerob $(97,7 \%)$ dan gram negatif $(86 \%)$. Jenis bakteri penyebab sepsis tersering di ruang stroke corner adalah Klebsiella pneumonia, Acinetobacter

Tabel 2. Distribusi Bakteri pada Pasien Stroke dengan Sepsis

\begin{tabular}{llc}
\hline Ruang Rawat & \multicolumn{1}{c}{ Bakteri } & n (\%) \\
\hline Stroke Corner & Staphylococcus hominis & $2(10,0)$ \\
& Klebsiella pneumonia & $8(40,0)$ \\
& Acinetobacter baumanii & $5(25,0)$ \\
& Escherichia coli & $1(5,0)$ \\
& Staphylococcus haemolyticus & $1(5,0)$ \\
& Enterobacter cloacae & $1(5,0)$ \\
& Staphylococcus capra & $1(5,0)$ \\
terpadu & Pseudomonas aeruginosa & $1(5,0)$ \\
& Klebsiella pneumonia & $5(21,7)$ \\
& Acinetobacter baumanii & $9(39,1)$ \\
& Escherichia coli & $3(13,0)$ \\
& Staphylococcus haemolyticus & $3(13,0)$ \\
& Staphylococcus epidermidis & $1(4,3)$ \\
& Pseudomonas aeruginosa & $2(8,6)$ \\
\hline
\end{tabular}

baumanii, dan Staphylococcus hominis; adapun di ruang rawat inap terpadu (Rindu) A4 Neurologi ditemukan sebanyak 6 bakteri penyebab sepsis, yaitu Acinetobacter baumanii, Klebsiella pneumonia, dan Escherichia colli (Tabel 2).

Hasil kultur mikrobiologi menunjukkan kuman di ruang stroke corner dan ruang rawat inap terpadu memiliki sensitivitas yang tinggi terhadap antibiotik amikasin meropenem, gentamisin, sefoprerazon, levofloksasin, seftazidin, dan doksisiklin (Tabel 3). 


\section{PEMBAHASAN}

Sebanyak $28,2 \%$ pasien stroke yang mengalami sepsis, lebih tinggi dibandingkan Berger dkk yang mendapatkan $12,6 \%$ pada 7 hari dari onset stroke. ${ }^{3}$ Demikian pula Fluri dkk menemukan 17,2\% subjek mengalami infeksi dalam 5 hari pascastroke. ${ }^{1}$ Berger mengambil subjek dari populasi pasien stroke yang dirawat di ruang intensif neurologi, sedangkan penelitian ini melibatkan juga ruang rawat biasa. Angka insidens sepsis lebih tinggi pada penelitian ini dapat disebabkan adanya perbedaan pada pola kuman dan tingginya angka infeksi nosokomial.

Kuman bakteri terbanyak pada penelitian ini adalah bakteri gram negatif, sedangkan penyebab sepsis Berger dkk adalah bakteri gram positif. Berdasarkan studi WHO pada 55 RS di 14 negara di seluruh dunia, menunjukkan bahwa $8,7 \%$ pasien menderita infeksi nosokomial selama menjalani perawatan, terutama di negara berkembang hingga lebih dari $40 \%{ }^{8}$

Disregulasi respons imun pada stroke akut berperan sebagai faktor predisposisi penting terjadinya infeksi pascastroke. ${ }^{1}$ Rerata durasi terjadinya sepsis pada penelitian ini adalah 5 hari, sejalan dengan penelitian Fluri dan Berger. Hal ini merupakan tahap cedera neurologis yang menunjukkan bahwa infeksi terkait dengan stroke dapat diinduksi secara imunologis melalui beberapa mekanisme. Hal ini didukung oleh adanya hubungan antara sistem saraf pusat dan sistem kekebalan tubuh. Setelah stroke terjadi cedera serebral yang memicu sekresi IL-1 $\beta$, TNF- $\alpha$, dan IL-6 dalam sel, yang merangsang paraventricular nucleus (PVN) untuk melepaskan corticotropin releasing factor (CRF). Corticotropin releasing factor terikat pada reseptor berganda G-protein dalam hipotalamus, untuk memediasi sekresi adrenocorticotropic hormone $(\mathrm{ACTH})$.

Adrenocorticotropic hormone menginduksi sekresi glukokortikoid dari zona fasikulata korteks adrenal yang menekan produksi mediator pro-inflamasi, termasuk IL-1, IL-11, IL-12, interferon $\gamma, \mathrm{TNF} \alpha$, kemokin (IL-8), prostaglandin dan nitrit oksida (NO). Glukokortikoid juga memudahkan pelepasan mediator antiinflamasi seperti IL-4, IL-10 dan transforming growth factor $\alpha$ dan memiliki sifat
Tabel 3. Sensitivitas Antibiotik di Ruang Stroke Corner dan Ruang Rawat Inap Terpadu

\begin{tabular}{|c|c|}
\hline Antibiotik & n (\%) \\
\hline \multicolumn{2}{|l|}{ Di Ruang Stroke Corner } \\
\hline - Gentamisin & $5(11,6)$ \\
\hline - Tetrasiklin & $4(9,3)$ \\
\hline - Vankomisin & $3(6,9)$ \\
\hline - Klindamisin & $2(4,6)$ \\
\hline - Eritromisin & $1(2,3)$ \\
\hline - Amikasin & $15(34,8)$ \\
\hline - Ampisilin/sulbaktam & $2(4,6)$ \\
\hline - Sefotaksim & $1(2,3)$ \\
\hline - Seftazidin & $4(9,3)$ \\
\hline - Seftriakson & $4(9,3)$ \\
\hline - Ertapenem & $2(4,6)$ \\
\hline - Siproflosaksin & $3(6,9)$ \\
\hline - Levofloksasin & $5(11,6)$ \\
\hline - Sefoprerazon & $6(13,9)$ \\
\hline - Trimetroprim/sulfametoksazol & $3(6,9)$ \\
\hline - Meropenem & $13(30,2)$ \\
\hline - Ofloksasin & $1(2,3)$ \\
\hline - Aztreonam & $1(2,3)$ \\
\hline - Azitromisin & $2(4,6)$ \\
\hline - Penisilin & $2(4,6)$ \\
\hline - Doksisiklin & $4(9,3)$ \\
\hline \multicolumn{2}{|l|}{ Di Ruang Rawat Inap Terpadu } \\
\hline - Gentamisin & $10(23,2)$ \\
\hline - Tetrasiklin & $3(6,9)$ \\
\hline - Vankomisin & $2(4,6)$ \\
\hline - Klindamisin & $1(2,3)$ \\
\hline - Eritromisin & $1(2,3)$ \\
\hline - Amikasin & $18(41,8)$ \\
\hline - Ampisilin/surbaktam & $1(2,3)$ \\
\hline - Sefotaksim & $1(2,3)$ \\
\hline - Seftazidin & $5(11,6)$ \\
\hline - Seftriakson & $3(6,9)$ \\
\hline - Ertapenem & $4(9,3)$ \\
\hline - Sefepim & $2(4,6)$ \\
\hline - Siprofloksasin & $2(4,6)$ \\
\hline - Levofloksasin & $5(11,6)$ \\
\hline - Sefoprerazon & $7(16,2)$ \\
\hline - Trimetoprim/sulfametoksazol & $4(9,3)$ \\
\hline - Moksifloksasin & $1(2,3)$ \\
\hline - Norfloksasin & $1(2,3)$ \\
\hline - Meropenem & $17(39,5)$ \\
\hline - Ofloksasin & $2(4,6)$ \\
\hline - Aztreonam & $1(2,3)$ \\
\hline - Azitromisin & $1(2,3)$ \\
\hline - Penisilin & $1(2,3)$ \\
\hline - Doksisiklin & $5(11,6)$ \\
\hline
\end{tabular}


antiproliferatif yang kuat, dan efek apoptosis, sehingga dapat memengaruhi kekebalan sel dan mempermudah terjadinya infeksi pascastroke. ${ }^{9}$

Pada penelitian ini didapatkan peningkatan kadar prokalsitonin $(6,93 \pm 14,36 \mathrm{ng} / \mathrm{mL})$, sejalan dengan Nasari dkk bahwa terdapat hubungan yang bermakna antara peningkatan kadar prokalsitonin dengan kejadian infeksi pascastroke. Prokalsitonin meningkatkan prediksi terjadinya infeksi terkait stroke dibandingkan dengan penanda prognostik lainnya. ${ }^{1}$

Elgazzar dkk juga menunjukkan hubungan peningkatan prokalsitonin dan stroke-associated pneumonia (SAP) dengan sensitivitas $87 \%$ dan spesifisitas $85 \%$ yang nilainya meningkat pada hari ketiga. Peningkatan nilai prokalsitonin pada penelitian ini kemungkinan disebabkan sebagai hasil dari pelepasan prokalsitonin oleh sel neuroendokrin pada lapisan mukosa bronkus dan juga dari selsel inflamasi lainnya yang umumnya karena invasi bakteri. Nilai prokalsitonin dapat mendukung diagnosis infeksi saluran pernapasan yang berhubungan dengan stroke. ${ }^{10}$

Sebagian besar subjek penelitian ini menderita stroke iskemik (81,4\%) sesuai dengan Nasari dkk yang menemukan jenis stroke iskemik yang terbanyak mengalami kejadian infeksi $(82 \%)$. Pada pasien stroke iskemik akut, terjadi peningkatan sel monosit di darah, dan menggambarkan perubahan fenotipe yang berkurang pada saat ekspresi dari molekul antigen dan rendahnya produksi dari TNF proinflamasi, juga produksi anti inflamasi IL-10 yang berubah. Perubahan ini penting yang berhubungan dengan risiko infeksi pascastroke. ${ }^{1}$

Sebagian besar subjek juga mengalami penurunan kesadaran pada awal masuk rumah sakit (86\%). Hal ini menunjukkan bahwa risiko sepsis lebih tinggi pada pasien stroke dengan penurunan kesadaran. Hal ini sejalan dengan penelitian Wandira dkk, yang menunjukkan bahwa risiko Stroke Associated Pneumonia juga terjadi pada pasien dengan penurunan kesadaran. ${ }^{11}$ Pasien dengan penurunan kesadaran dapat mengalami penurunan protektif refleks batuk, gangguan sfingter bawah esofagus dan gangguan koordinasi antara bernapas dan menelan sehingga dapat mencetuskan aspirasi.
Selain itu, pasien dengan penurunan kesadaran lebih sering terpapar tindakan seperti pemakaian nasogastric tube, suction, dan kateter yang dapat memicu terjadinya infeksi. ${ }^{8}$ Pada penelitian ini, walaupun pasien dalam keadaan imobilisasi tetapi sudah dilakukan fisioterapi pasif dan aktif, sehingga diperkirakan pasien mengalami infeksi karena adanya imunodepresi akibat stroke yang menyebabkan pasien berisiko lebih tinggi untuk mengalami infeksi selama di RS.

Pada penelitian ini bakteri terbanyak penyebab sepsis pada pasien stroke di ruang stroke corner adalah Klebsiella pneumonia (40,0\%). Klebsiella pneumonia termasuk dalam kelas Enterobacteriaceae yang banyak terdapat di saluran napas dan feses, dan kelas ini merupakan penyebab paling umum infeksi yang didapat di rumah sakit, seperti infeksi saluran kemih, infeksi aliran darah, pneumonia, dan infeksi abdomen. Bakteri ini mampu memproduksi enzim extended spectrum beta lactamase (ESBL) yang dapat melumpuhkan kerja berbagai jenis antibiotik. Selain ESBL, resistensi terhadap sefalosporin generasi ketiga juga dapat disebabkan oleh produksi enzim Ampc Cephamycinase (AmpC) terutama oleh Enterobacter spp dan Citrobacter spp yang dikode oleh gen AmpC di kromosom. ${ }^{12-13}$

Bakteri terbanyak penyebab sepsis pada pasien stroke yang dirawat di ruang rawat inap terpadu adalah Acinetobacter $39,1 \%$ yang merupakan patogen oportunistik penting yang berkembang pesat menuju resistensi multiobat dan terlibat dalam berbagai infeksi nosokomial. Bakteri ini termasuk gram negatif genus Acinetobacter yang terdiri dari banyak spesies yang ditemukan selama 3 dekade terakhir. Infeksi nosokomial yang disebabkan oleh strain Acinetobacter baumannii menjadi masalah klinis akibat kemampuannya untuk beradaptasi dengan kondisi rumah sakit yang tidak menguntungkan serta resisten terhadap antibiotik dan agen desinfektan. ${ }^{14}$

Acinetobacter baumannii juga memiliki ketahanan tinggi terhadap pengeringan yang memungkinkannya bertahan hidup sekitar 27 hari pada permukaan kering. Patogen ini sering dibawa oleh tenaga medis, sehingga berisiko infeksi bagi pasien yang dirawat inap, kondisi keseluruhan yang buruk, insufisiensi sistem sirkulasi dan pernapasan, 
terapi antibiotik sebelumnya, serta penggunaan ventilasi mekanis, kateter vena, arteri, dan kateter urin. ${ }^{14}$

Perbedaan jenis bakteri pada kedua ruangan ini dapat dipengaruhi oleh beberapa faktor, seperti perbedaan karakteristik ruangan, perbedaan dari pasien yang dirawat, dan perbedaan pada karakteristik bakteri yang menginfeksi. Ruang stroke corner merupakan ruang perawatan intensif untuk pasien stroke pada fase akut. Ruangan ini terdiri dari 5 tempat tidur pasien dengan monitor. Keluarga tidak dapat menemani pasien dan pengunjung pada ruangan ini juga dibatasi. Jendela ruangan juga selalu tertutup karena menggunakan penyejuk udara, sehingga suhu ruangan selalu dingin.

Suhu ruangan yang rendah dan ruangan tertutup menyebabkan kurangnya cahaya matahari yang masuk, sehingga tingkat kelembaban juga semakin tinggi. Hal ini juga memudahkan terjadinya infeksi bakteri, seperti Klebsiella pneumonia. Bakteri ini mampu memproduksi enzim extended spectrum beta lactamase (ESBL) yang dapat menyebabkan resistensi multiobat, sering di ruang perawatan intensif. ${ }^{13}$ Selain itu, pasien-pasien yang dirawat di ruang intensif umumnya mempunyai imunitas yang rendah, pemantauan keadaan secara invasif, terpapar dengan berbagai jenis antibiotik, dan terjadi kolonisasi oleh bakteri resisten, sehingga memiliki potensi yang lebih besar mengalami infeksi. ${ }^{15}$

Adapun ruang rawat inap terpadu ditujukan untuk perawatan pasien stroke di luar fase akut, bergabung dengan pasien lain, baik pasien stroke maupun bukan stroke. Satu ruangan terdiri dari 6 tempat tidur dan dapat ditemani oleh pihak keluarga. Ruangan tidak dilengkapi dengan penyejuk ruangan serta memiliki jendela dan pintu terbuka, sehingga memungkinkan udara dan cahaya matahari dapat masuk. Pada ruangan ini bakteri yang lebih banyak dijumpai adalah Acinetobacter baumannii. Bakteri ini memiliki kemampuan untuk bertahan dalam lingkungan yang kurang menguntungkan, memiliki ketahanan tinggi terhadap pengeringan yang memungkinkannya bertahan hidup sekitar 27 hari pada permukaan kering. ${ }^{14}$

Pada penelitian ini jenis bakteri terbanyak dijumpai adalah bakteri aerob $(97,7 \%)$ dan gram negatif (86\%). Umumnya mikroorganisme yang dijumpai pada infeksi nosokomial lebih mengarah kepada bakteri-bakteri gram negatif dengan angka kejadian multi- atau pan- resisten yang tinggi. Hal ini disebabkan karena terjadinya berbagai perubahan karakteristik mikroorganisme di RS yang secara garis besar disebabkan oleh proses endogenik seperti pemberian antimikroba dengan durasi dan adekuasi yang kurang tepat maupun proses eksogenik seperti terjadinya mutasi genetik pada mikroorganisme di

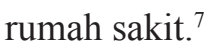

Infeksi terbanyak pada penelitian ini adalah pneumonia $(67,4 \%)$, yaitu dalam minggu pertama awitan stroke. Hal ini kemungkinan mencerminkan periode risiko tertinggi dalam hal prevalensi disfagia, imobilisasi, gangguan kesadaran, dan adanya penekanan pada respons imun pada pasien stroke. ${ }^{13}$ Hal ini sesuai dengan penelitian di beberapa RS di Indonesia mengenai pola kuman di ruang perawatan intensif, bahwa infeksi terbanyak adalah pneumonia. ${ }^{8}$

Pneumonia dapat disebabkan adanya aspirasi organisme orofaring ke bronkus distal, terjadi pembentukan biofilm oleh bakteri diikuti dengan proliferasi dan invasi bakteri pada parenkim paru. Pada keadaan normal, organisme di dalam rongga mulut dan orofaring didominasi oleh S. viridans, Haemophilus species, dan organisme anaerob. Air liur yang mengandung imunoglobulin A (Ig A) dan fibronektin menjaga keseimbangan organisme rongga mulut, sehingga jarang didapatkan basil gram negatif aerobik. Pada pasien sakit kritis keseimbangan tersebut berubah, organisme yang dominan di dalam rongga mulut adalah basil gram negatif aerobik dan Staphylococcus aureus. ${ }^{15}$

Penelitian ini memiliki keterbatasan, antara lain penelitian ini tidak membandingkan derajat keparahan penyakit dan defisit neurologi berat dengan risiko terjadinya sepsis, serta tidak membandingkan jumlah dilakukannya fisioterapi dengan risiko terjadinya sepsis.

\section{KESIMPULAN}

Didapatkan 28,2\% pasien stroke yang mengalami sepsis dengan bakteri terbanyak penyebab sepsis di ruang stroke corner adalah Klebsiella pneumonia $(40,0 \%)$, sedangkan di ruang rawat inap 
terpadu yaitu Acinetobacter baumanii (39,1\%) yang merupakan bakteri aerob gram negatif. Amikasin dan meropenem merupakan antibiotik yang memiliki sensitivitas yang tinggi terhadap bakteri penyebab sepsis tersebut.

\section{DAFTAR PUSTAKA}

1. Nasari RV, Rambe AS, Fithrie A. Hubungan kadar leukosit, monosit dan prokalsitonin dengan kejadian infeksi dan luaran fungsional pada stroke akut. Neurona. 2018;35(2):137-43.

2. Grimnes $\mathrm{G}$, Isaksen $\mathrm{T}$, Tichelaar YIGV, Braekkan SK, Hansen JB. Acute infection as a trigger for incident venous thromboembolism: results from a population-based casecrossover study. Res Pract Thromb Haemost. 2018;2:85-92.

3. Berger B, Gumbinger C, Steiner T, Sykora M. Epidemiologic features, risk factors, and outcome of sepsis in stroke patient treated on a neurologic intensive care unit. J Critical Care. 2014:29(2):241-8.

4. Rhodes A, Evans LE, Alhazzani W, Levy MM, Antonelli M, Ferrer R, Kumar, dkk. Surviving sepsis campaign: international guidelines for management of sepsis and septic shock. Critical Care Medicine. 2017:45(3):486-552.

5. Singer $\mathrm{M}$, Deutschman CS, Seymour CW, Hari MS, Annane D, Bauer M, dkk. The third international consensus definitions for sepsis and septic shock (sepsis-3). J Am Medical Association. 2016:315(8):801-10.

6. Pangalila FJV. Patofisiologi sepsis dan syok septik. Dalam: Pangalila, FJV, Sugiman T, editor. Penatalaksanaan sepsis dan syok septik surviving sepsis campaign bundle. PERDICI. Jakarta: 2014. h. 5-14.

7. Hermawan G. Infeksi nosokomial. Dalam: Sofiati
S, Alwi I, Sudaya AW, Simadibrata M, Setiyahadi B, Syam AF, editor. Buku ajar ilmu penyakit dalam. Edisi ke-6. Jakarta: Interna Publishing; 2014. h. 68291.

8. Taslim E, Maskoen TT. Pola kuman terbanyak sebanyak agen penyebab infeksi di intensive care unit pada beberapa rumah sakit di indonesia. J Anesth Crit Care. 2016:34(1):56-62.

9. Li L, Zhang LH, Xu WP, Hu JM. Risk assessment of ischemic stroke associated pneumonia. World J Emerg Med. 2014;5(3):209-213.

10. Elgazzara AEM, Hosnyb H, Elkhateeb TH. Procalcitonin and clinical pulmonary infection score as predictors of stroke-associated pneumonia: a prospective observational single-center study. The Japanese Journal of Tuberculosis and Chest Diseases. 2018;20(20):2090-9950.

11. Wandira RD, Amalia L, Fuadi I. Hubungan antara derajat keparahan stroke dengan kejadian strokeassociated pneumonia. Neurona. 2018;35(2):116-20.

12. Keputusan Menteri Kesehatan Republik Indonesia. Pedoman nasional pelayanan kedokteran tata laksana sepsis: 2017.

13. Saharman YR, Lestari DC. Phenotype characterization of beta-lactamase producing enterobacteriaceae in the intensive care unit (ICU) of Cipto Mangunkusumo hospital in 2011. Indonesian J Internal Med. 2013:45(1):11-6.

14. Sieniawski K, Kaczka K, Rucinska M, Gagis L, Pomorski L. Acinetobacter baumanii nosocomial infections. Polski Przeglad Chirurgigzny. 2013:85(9):483-90.

15. Smith CJ, Kishore AK, Vail A, Chamorro A, Garau $\mathrm{J}$ and Hopkins SJ. Diagnosis of stroke-associated pneumonia recommendations from the pneumonia in stroke consensus group. Stroke. 2015;46:2335-40. 